\title{
Maintenance of keypecking in pigeons by a food avoidance but not by a shock avoidance contingency*
}

\author{
BARRY SCHWARTZ \\ Swarthmore College. Swarthmore. Pennsilliania 19081
}

\begin{abstract}
Response ke! illuminations were followed by food delivery or shock. and keypecks were programmed to prevent the occurrence of whichever stimulus was scheduled. At high shock intensity. pigeons did not peck: at low shock in tensity. pigeons pecked in about half of the trials. When different key colors signaled food and shock trials. pigeons pecked on food trials. thus preventing food delivery. but not on shock trials. thus failing to avoid shock delivery. That pecks occurred despite the fact that they avoided food but did not occur when they avoided shock is taken as evidence that the keypeck is frequently governed by biological predispositions. and not by its consequences.
\end{abstract}

Recent research has indicated that pigeons will peck at a response key that is regularly illuminated just prior to food delivery. even when keypecks function to prevent the delivery of food (Schwartz, 1972; Schwartz \& Williams. 1972a. b: Williams \& Williams, 1969). This negative automaintenance procedure is formally analogous to the classical discrete-trial avoidance procedure. It is thus a striking paradox that. while pigeons readily peck a key when keypecks result in the aroidance of food. they learn to peck a key when keypecks result in the avoidance of painful electric shoik with great difficulty. if at all (Azrin. 1959: Hoftman \& Fleshler. 1959: Hineline \& Rachlin. 1969: Rachlin \& Hineline. 1967). The present study involved a within-S within-session comparison of the effectiveness of food avoidance (negative automaintenance) and shock aroidance contingencies in maintaining keypecking.

\section{METHOD}

\section{Subjects}

Three Silver King pigeons. deprived to $80 \%$ of free-feeding weight. had a history of unsuccessful shock avoidance training. That procedure consisted of periodic 6-sec illuminations of a response key which were followed by painful electric shock. Keypecks prior to shock aroided the shock. while keypecks during the shock escaped it.

\section{Apparatus}

One wall of a standard pigeon chamber housed a single response ker that could be illuminated with green or red light. A lood magazine was located below the ke! and an amber houselight was located above the key. The wall was painted flat black. The shock source was a Grason-Stadler shock generator (Model To. E106+1. Which was connected with alligator clips through the ceiling of the chamber to wire bands secured around eash of the pigeon's wings (Hoffman \& Fleshler. 19591. The clips were attached to the wing bands at the start of each session. including those in which no shocks were scheduled.

*This research was supported by a grant from the Sloan Foundation to Swarthmore College. I wish to acknowledge the ussistance of Kenneth Klothen and the critical advice of Allen $M$. Schneider and Yy ma Sihw artz.

\section{Procedure}

Table 1 includes a summary of the sequence of procedures in the experiment. The pigeons were first exposed to a negative automaintenance procedure. The response key was periodically illuminated with green light for $6 \mathrm{sec}$. followed by $6 \mathrm{sec}$ access to mixed grain. A peck to the lit key prevented food. Each session consisted of 50 trials. separated by a variable intertrial interval with a mean of $40 \mathrm{sec}$. After seven sessions, a 1.3-m.A shock was substituted for food in a random half of the trials. On these trials. pecks to the illuminated key either avoided or escaped the shock. The remaining half of the trials were negative automaintenance trials. as before. After seven sessions of this procedure. the shock trials were eliminated for seven sessions. The shock avoidance trials were then reintroduced. this time with the shock level set at $0.7 \mathrm{~m} . \mathrm{A}$. For seven sessions. the key was always green. Then a red keylight was introduced. so that food and shock trials were associated with green and red. respectively. After 10 sessions of this procedure. the experiment was terminated for two of the pigeons. Pigeon 3 was run for seven additional sessions. this time with shock intensity rajsed to $1.3 \mathrm{~mA}$

\section{RESULTS}

Table 1 presents the percentage of trials in which a response occurred on negative automaintenance and shock avoidance procedures for each pigeon. The data are averaged across the last three sessions of each procedure. Though the pigeons pecked on between $40^{\circ}$, and $76 \%$ of the negative automaintenance trials. when shock trials were introduced pecking essentially ceased. When shock trials were omitted, pecking returned almost to its initial level. When shock trials were reintroduced. this time with lower intensity shock. the frequency of pecking was almost unchanged. At this point. the discrimination procedure was instituted. Pigeons 1 and 2 rapidly came to peck almost exclusively on negative automaintenance trials. Pigeon 3 continued pecking on both kinds of trials. However. when shock intensity was returned to $1.3 \mathrm{~mA}$. Pigeon 3 virtually stopped pecking but. again. in both negative automaintenance and shock avoidance trials. Thus, this pigeon gave no indication of having acquired a discrimination on the basis of key color. 
Table 1

Percentage of Trials With Response in the Last Three Sessions of Each Procedure

\begin{tabular}{|c|c|c|c|c|c|}
\hline Automaintenance & $\begin{array}{l}\text { Shock Intensity } \\
\text { (m. }\end{array}$ & $\begin{array}{c}\text { Number } \\
\text { of Sessions }\end{array}$ & $\mathrm{P} 1$ & $\mathrm{P} 2$ & P 3 \\
\hline Negative & & 7 & 46 & 40 & 76 \\
\hline Negative & 1.3 & 7 & 0 & 0 & 8 \\
\hline Negative & - & 7 & 46 & 36 & 60 \\
\hline Negative & 0.7 & 7 & 40 & 28 & 60 \\
\hline Discriminated Negative & 0.7 & 10 & $37\left(7^{*}\right)$ & $31(2)$ & $46(45)$ \\
\hline Discriminated Negative & 1.3 & 7 & - & - & $10(8)$ \\
\hline
\end{tabular}

* Numbers in parentheses indicate percent successful shock aroidance. They are adjacent to percent negative automaintenance trials with a response.

\section{DISCUSSION}

This experiment demonstrates that. when negative automaintenance and shock avoidance procedures are directly compared. pecks which result in the avoidance of food are maintained. while pecks which result in the avoidance of shock are not. In the procedures in which food trials and shock trials were not correlated with different key colors. the pigeons pecked frequently when shock intensity was low $(0.7 \mathrm{~mA})$ and ceased pecking when shock intensity was high $(1.3 \mathrm{~mA})$. There are two possible explanations for this phenomenon. First, it is possible that high shock intensity elicits behavior that is incompatible with keypecking. while low shock intensity does not (see Smith et al, 1972). If the key stimulus becomes a conditioned elicitor of this incompatible behavior. then the behavior will interfere with peiking. The problem with this explanation is that close observation of the pigenns during both high and lou shock sessions failed to reveal any sign of behavior that was incompatible with key pecking before shocks occurred. The second possible explanation is that the pigeons form an all or none assoilation between the keylight and either shock or food: which stimulus is associated with the key is a function of the salience of the two stimuli. Thus. intense shock is prepotent over food, while a mild shock is less potent than food. As a result. at high shock intensity the pigeons behave as if each trial were a shock trial. while at low shock intensity the pigeons behave as if each trial were a food trial. As the discrimination procedure indicates. when the key is a signal for shock. no pecking occurs: when the key is a signal for food. frequent pecking ocurs.

The question this explanution leaves unanswered is why no keypecking occurs and why keypecking that is already established ceases when the key is a signal for shock. One possibility is that. through association with shock. the response key becomes aversive and as a result. pecks are not directed at it. In most other signaled avoidance procedures (e.g.. shuttlebox or barpress). the required response is not directed at the signal. so that the possible arersireness of the signal would offer no interference with the acquisition of the response. This explanation implies that the stimulus-stimulus relat ionship (he?-shoit) dominates the response-reinforcer relationship (peck-avoidance) in the present experimental procedure.

A second possibility conforms to arguments made recently about the significance of species-specific influences on the control of behavior by reinforcement contingencies (Bolles. 1970: Seligman, 1970: Seligman \& Hager. 1972: Schwartz \& Williams, 1972b). Bolles has argued that the most significant determinant of whether avoidance learning will occur is whether the response chosen to be trained is a species-specific defense reaction (SSDR). Clearly, in the pigeon pecking is not an SSDR. Other research indicates that wing flapping (Rachlin. 1969), flying (Bedford \& Anger, 1968), and locomotion (Macphail. 1968) may be SSDRs. On the other hand. Schwartz and Williams have argued that a factor which partially controls pecking in appetitive situations is that the peck is part of the pigeon's normal repertoire of consummatory behavior. Thus, when the response key signals food. pecks occur despite the fact that they prevent food delivery. and, when the response ke! signals shock. pecks do not occur (they are not SSDRs) despite the fact that they successfully avoid shock. In both cases. it is the relationship of the procedure to the organism's built-in behavioral repertoire, rather than the contingencies within the procedures themselves, which primarily determines the result.

\section{REFERENCES}

Azrin. X. H. Some note's on punishment and avoidance. Journat of the Lxperimental Anal! sis of Behavior. 1959. 2. 260.

Bedford. I.. \& Anger. D. Flight as an dvoidance response in pigeons. Paper prevented at the meeting of the Psichonornic Society. St Louls. Ostober 1968.

Bolles. R. (C. Sprivespecific defense reactions and aroidanis learning. Psuchological Review. 1970. 77. 32-48.

Hineline. P. . . \& Ruchlin. H. Escape and aroidans of shosk ty pigeons pecking a kes. Journal of the Experimental Anais us of Behavior. 1969. 12.533-538.

Hofiman. H. S.. \& 1 lewhler. M. Aversive control with the pigeon. Journal of the L uperimental Analysis of Beharior. 1959. 2. $213-218$

Macphail. I. M. Aloidane responding in pigeons. Journal of the Experimental Analus of Bellavior. 1968.11.625-6:?

Rachlin. H. Autwhapme of ke' pesing in pigeons with neams reinforcinent. Journal of the Everinental tnelson of

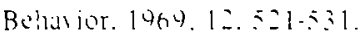

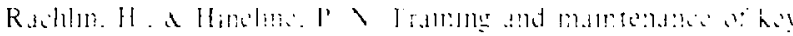


pecking in the pigeon by negative reinforcement. Science. 1967.157 .954 .955

Schwartz. B. The role of positive conditioned reinforcement in the maintenance of keypecking which prevents delivery of primary reinforcement. Psichonomic Science. 1972. 28. 277.278 .

Schwartz. B.. \& Williams. D. R. The role of the response-reinforcer contingency in negative automaintenance. Journal of the Experimental Analysis of Behavior. 1972a. 17. $351-357$

Schwartz. B.. \& Williams. D. R. Two different kinds of key peck in the pigeon: Some properties of responses maintained by negative and positive response-reinforcer contingencies. Journal of the Experimental Analysis of Behavior. 1972b. 18. $201-216$

Seligman. M. E. P. On the generality of the laws of learning.
Psychological Review, 1970, 77, 406-418.

Seligman. M. E. P.. \& Hager. J. Biological boundaries of learning New York: Appleton-Century-Crofts. 1972.

Smith. R. F.. Gustavson. C. R.. \& Gregor. G. L. Incompatibility between the pigeon's unconditioned response to shock and the conditioned key peck response. Journal of the Experimental Analysis of Behavior. 1972. 18. 147-153.

Williams. D. R.. \& Williams, H. Automaintenance in the pigeon: Sustained pecking despite contingent non-reinforcement. Journal of the Experimental Analysis of Behavior. 1969. 12. $511-520$

(Received for publication December 18. 1972: revision received March 5. 1973: accepted March 14, 1973.) 